\title{
Bersanding dalam resepsi perkawinan: refleksi atas pandangan dan perilaku hukum di Kota Palangka Raya
}

\author{
Abdul Helim \\ STAIN Palangka Raya \\ abdulhelim@yaboo.com
}

According to the seven marriage couples and three fatwa givers which become of the subjects of the study, the mixture of the place for the bride and the groom is prohibited (baram) because it can provoke fitnab, there is tabarruj, ask for the highest bride price, focus more on the gifts, and money from the guests and the other people who spread out the yellow rice. The doers don't know the legal arguments and even taqlid to the fatwa givers but they don't have reliable arguments. The doers only argue that life of men and women should be separated as in salat and there is no nas that allows the bride and the groom to sit next to each other. Ikbtilat is allowed to do in the market or workplace because was practiced during prophet Muhammad SAW' life. This argument is weak and hard to accept and it traps us because there is a great potency of disadvantage between Ikbtilat in the market and work place compared to Ikbtilat in wedding reception.

Keywords: Wedding ceremony; Marriage; Ușül Fiqh; Fatwa

\section{Pendahuluan}

Salah satu ketentuan yang diatur dalam hukum perkawinan Islam adalah mengadakan resepsi perkawinan (watimah al-wrs). Acara ini diselenggarakan sebagai rasa syukur kepada Tuhan, karena telah bersatunya dua jenis manusia yang berbeda dalam ikatan suci untuk membina rumah tangga. Acara ini juga merupakan media untuk menyatakan kedua mempelai resmi menjadi suami isteri, bahkan sesuai dengan maknanya, tesepsi perkawinan merupakan acara yang diselenggarakan untuk menjamu kerabat, sahabat dan masyarakat muslim yang datang menyaksikan ikatan suci tersebut. 
ljtihad, Jurnal Wacana Hukum Islam dan Kemanusiaan, Vol 11, No. 2, Desember 2011: 165-181

Menyelenggarakan acata ini tidak hanya mengandang kebazan, bahkan mayoritas para pakar usul fikih memandang resepsi perkawinan termasuk sunnah ma'akeadah (Sabiq, jilid II, 1995: 273). Nabi Muhammad sendiri menyelenggaralan resepsi ini dan menganjurkan pula untuk menyelenggarakannya, walau dengan acara jang sangat sederhana (Bukhari, juz III, t.t.: 379-380).

Puncak acara resepsi perkawinan ini adalah bersanding yakni seorang laki-laki dan perempuan yang telah melakukan jijab gabal serta resmi menjadi suami isteri duduk berdua berdampingan di atas pelaminan. Keduanya dihiasi sehingga tampak gagah dan cantik serta menggunakan pakaian lengkap baik berpakaian nacional atau pun berpakaian adat. Keduanya juga disaksikan oleh tamu yang datang baik laki-laki atau pun perempuan, anak-anak, remaja atau pun dewasa sambil menyalami keduanya seraya mendoakan semoga Tuhan memberkati keduanya dalam membina rumah tangga.

Persoalan yang ditemukan ada yang mengharamkan acara bersanding secara mutlak (ElIndragiry, 2008: 1), ada pula yang mengharamkannya secara bersyarat yakni hanya ketika terdapat perilaku hukum yang menyimpang dari ajaran Islam mengelabui ( $($ a $d$ lis $)$ atau merubah ciptaan Tuhan seperti mewarnai kuku dan mencukur sebagian bulu kening dan berhias untuk dipertontonkan (tabarruj) (al-Qustany, 2009: 1), atau terikat dan mendahulukan adat (ditaburi beras kuning dan dibacakan mantera (Jawas, 2010: 1). Bersanding juga dipandang haram apabila banyak menghabiskan uang sehingga dianggap sebagai pemborosan, menjadikan uang atau hadiah sebagai suatu kemestian, maskawin atau mahar yang mahal, bahkan $a_{\mathrm{L}}$ abila kedua mempelai yang bersanding ini menyebabkan bercampur baurnya tamu laki-laki dan perempuan (ikbtila $\bar{t}$ ) yang mestinya menurut mereka, tempat jamuan untuk tamu dipisah sesuai dengan jenis kelamin (Hanif, 2007: 1).

Sebagian masyarakat muslim Kota Palangka Raya tampaknya ada juga yang memiliki pandangan dan perilaku hukum serupa dengan yang diuraikan di atas. Salah satu peristiwa yang tampak unik, kedua mempelai yang secara legal telah resmi menjadi suami isteri dan mestinya disandingkan karena tidak ada halangan hukum untuk memisahkan keduanya, namun ketika resepsi, keduanya dipisah pada pelaminan yang berbeda.

Permasalahan di atas cukup menarik untuk dikaji secara ilmiah, metodis dan maksimal sesuai dengan kapasitas yang dimiliki untuk mengkaji ulang argumentasi-argumentasi yang 
Bersanding dalam resepsiperkawinan: refleksiatas pandangan dan perilaku hukum...(Abdul Helim)

dikemukakan sebagian masyarakat muslim Kota Palangka Raya yang memiliki pandangan dan perilaku hukum yang sama dengan beberapa "fatwa" dalam beberapa artikel di atas. Masalah yang dikaji sekitar perilaku-perilaku hukum yang dianggap haram dalam acara bersanding saat resepsi perkawinan, argumentasi hukum yang dijadikan sebagian masyarakat muslim Kota Palangka Raya sebagai dasar untuk menyatakan haramnya persandingan, dan metode istinbät yang digunakan pemberi fatwa haramnya bersanding saat resepsi perkawinan bagi mempelai di Kota Palangka Raya.

Kajian tentang hukum bersanding bagi mempelai saat resepsi perkawinan sebenarnya telah ada yang mengkajinya seperti Muhammad Basyir yang memfokuskan pada tradisi pemilihan calon isteri dan tata cara pelaksanaan watimah 'urs bagi anggota Hizbut Tahrir di Kota Palangka Raya. Hasil penelitian ini adalah tradisi pemilihan calon isteri bagi anggota Hizbut Tahrir di Kota Palangka Raya tampak eksklusif, sebab mereka lebih memilih perempuan yang menjadi anggota Hizbut Tahrir daripada perempuan yang lain. Tata cara pelaksanaan walimah al-urs, pengantin laki-laki dan pengantin perempuan tidak duduk pada satu persandingan. Begitu pula para tamu dipisah atau diberi pembatas antara tamu laki-laki dengan tamu perempuan (Basyir, 2008).

Kajian lainnya hanya dapat diperoleh melalui beberapa artikel yang diposting di berbagai weblog, namun tampaknya sebagian besar artikel tersebut menggunakan redaksi yang sama antara satu webblog dengan webblog lainnya yang esensinya mengharamkan beberapa kegiatan dhlam acara persandingan seperti menabur beras kunyit, membaca mantera, tadlis (mempercantik diri dengan cara merubah ciptaan Tuhan), tabarmij (berhias untuk dipamerkan), kcnduri walimah secara besar-besaran (aruh), mengutamakan hadiah, menentukan mas kawin dan bantaran secara mahal, dan ikhtilät (campur baur antara laki-laki dan wanita) (al-Qustany, 2009: 1).

Argumentasi-argumentasi yang disajikan dalam beberapa artikel di atas dan metode ásiabat yang digunakan tampaknya masih mengandung celah untuk diteliti. Hal ini terlihat dari argumentasi yang dikemukakan masih belum tuntas dan ketidakjelasan metode yang digunakan. Penelitian ini juga tidak terfokus pada organisasi tertentu sebagaimana yang diteliti Basyir, sebab di antara beberapa mempelai yang menyelenggarakan resepsi perkawinan dengan praktik serupa di kota Palangka Raya ini ada yang tidak atau bukan berasal dari organisasi tertentu. 
ljtihad, Jurnal Wacana Hukum Islam dan Kemanusiaan, Vol. 11, No. 2, Desember 2011: 165-181

Data penelitian kasus dengan karakteristik penelitian kualitatif lapangan ini digali da tujuh pasangan suami isteri dan tiga orang pemberi fatwa yang ditentukan melalui teknita purposive sampling. Data yang terkumpul dianalisis menggunakan metode content analysis dengart langkah, data yang berkaitan dengan dasar argumentasi dianalisis dengan cara memahan maksud (maqāasbid) lafal dan kalimat yang terdapat pada dasar-dasar hukum atau pun hasi pemikiran yang digunakan dan didukung pula melalui aturan-aturan kebahasaan dalam ilm.

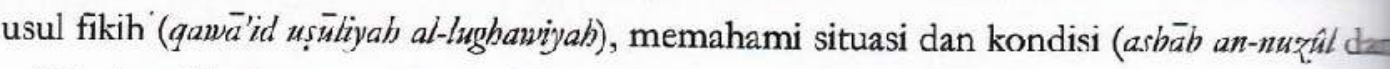
as bäb al-2nurüd) dan mengkontekstualisasikan dasar-dasar hukum atau pun hasil pemikira dengan zaman sekarang sesuai dengan teori double movement Fazlur Rahman (Rahman, 1989 25-26) dan (Rahman, 1992: 63) yang kemudian dipertimbangkan pula melalui metode an serta didukung kaidah-kaidah fikih (qawä'id al-figbiyab). Data yang berkaitan dengan metode istinbät yang digunakan dianalisis dengan cara melacak qawäid usüitivah al-highawiyah dan metode (manbaj) usul fikih yang digunakan serta mengkaji pula relevansi istinbät. hukum yang digunakan pemberi fatwa dengan metode-metode (manābij) ilmu usul fikih.

\section{Perilaku hukum yang dianggap haram dalam acara bersanding}

Ketujuh pasangan suami isteri yang menjadi subjek penelitian ini memiliki pandangan yang sama bahwa perilaku hukum yang dianggap haram ketika resepsi perkawinan adalah menyandingkan atau bersandingnya mempelai pada pelaminan yang sama dan tidak membuat bijäb antara tamu laki-laki dan wanita. Hal ini dapat menyebabkan bercampur baurnya tamu yang buk 'n muhrim dan sambil menikmati hidangan sangat memungkinkan terciptanya sebuah "obrolan" di antara tamu laki-laki dan perempuan yang berpotensi menimbulkan fitnah atau bahkan mengarahkan pada yang diharamkan Allah.

Dipandang dari sudut lain, haramnya bersanding adalah agat terhindarnya para tamu laki-laki menyalami mempclai perempuan atau sebaliknya. Menurut subjek upaya tersebut dilakukan untuk menghindari persentuhan orang-orang yang bukan muhrim dan menghindari pula adanya potensi ketertarikan di antara para tamu laki-laki terhadap mempelai perempuan atau sebaliknya, bahkan memungkinkan pula cinta mempelai laki-laki pada isterinya berubah disebabkan telah melihat di antara para tamu perempuan ada yang lebih cantik dari isterinya sendiri. Mempertimbangkan beberapa hal di atas, menurut subjek Islam telah benar mengatur 
Bersanding dalam resepsi perkawinan: refleksi atas pandangan dan perilaku hukum...(Abdul Helim)

pentingya hijāb antara laki-laki dan perempuan dan termasuk pula kemestian ber hijäb ketika melangsungkan resepsi perkawinan dengan cara memisahkan pelaminan mempelai laki-laki dan perempuan serta memisahkan pula tempat perjamuan tamu laki-laki dan perempuan.

Model resepsi perkawinan yang diperkenalkan sebagian masyarakat muslim ini patut dipandang sebagai salah satu upaya untuk melaksanakan syariat Islam dalam kehidupan sehari-hari. Apabila hal ini dilakukan dengan komitmen yang tinggi dan tidak hanya bersifat formalistik sehingga dinilai sebagai muslim formatif serta teraplikasi pula pada persoalanpersoalan kehidupan yang lain, tampaknya mereka dapat dijadikan sebagai model atau miniature muslim yang konsisten. Persoalan yang masih menggelitik, ketika melakukan observasi baik sebelum atau ketika melakukan penelitian, ditemukan perilaku berulang baik dari para subjek sendiri maupun orang-orang yang sepaham dengan mereka yang sebenarnya perilaku tersebut bertentangan dengan komitmen mereka. Ketika mengadakan prosesi inti dari perikatan perkawinan yakni $\bar{j} j \bar{a} b$ dan qabül, para subjek atau kedua calon mempelai yang sebenarnya belum resmi menjadi suami isteri bersanding (berdampingan) duduk menghadap penghulu atau Petugas Pencatat Nikah dari Kantor Urusan Agama. Hadir dalam prosesi ini tidak hanya dari orang tua dan kerabat dekat para subjek atau kedua calon mempelai, tetapi dihadiri pula oleh orang lain (ajnabl) termasuk penghulu dan saksi. Jika subjek atau kedua calon mempelai konsisten, mestinya calon mempelai perempuan tidak terlihat sama sekali (bijäb). Fakta yang ditemukan mereka melakukan ikhtilät, setidaknya dapat dilihat dari kehadiran calon mempelai perempuan di tengah-tengah prosesi inti itu.

Ketidakkonsistenan ini akhirnya menimbulkan penilaian bahwa para subjek tampaknya gegabah dalam memahami ajaran Islam, khususnya pada hukum bersanding dalam resepsi perkawinan. Para subjek dapat dikatakan terjebak dalam pemahaman formalistik yang cenderung literal, sehingga dari kegiatan-kegiatan yang dilakukan sebagiannya ada yang ingin dipertontonkan kepada masyarakat bahwa mereka adalah pelaksana hukum Tuhan yang baik, namun pada sebagian yang lain komitmen yang dikemukakan justru diabaikan.

Sebagian besar subjek menyatakan ketidaktahuan mereka terhadap perilaku-perilaku yang dianggap haram dalam bersanding, kecuali konsep ikhtilät di atas, dan sebagian kecil lainnya mengatakan haramnya bersanding disebabkan adanya nuansa tabarrij yakni berhias atau berperilaku untuk dipertontonkan. Menurut subjek, apabila kedua mempelai disandingkan 
Ijtihad, Jurnal Wacana Hukum Islam dan Kemanusiaan, Vol. 11, No. 2, Desember 2011: 165-181

pada satu pelaminan, maka mempelai perempuan baik berkeinginan atau sebaliknya akan tetap menjadi bahan tontonan para tamu khususnya laki-laki (ajnabi) yang sebenarnya hanya suaminya yang berhak menikmati kecantikan isterinya.

Nuansa atau bahkan tabarruj itu sendiri mesti dihindari yang artinya tidak hanya dalam resepsi perkawinan, melainkan termasuk pula dalam setiap kegiatan kehidupan. Seorang isteri atau perempuan yang baik, sebenarnya hanya menampakkan perhiasan dan kecantikannya bahkan menutup hal-hal yang terlarang dilihat orang asing hanya untuk suaminya. Hal ini juga merupakan sebuah tanda kehormatan bagi seorang perempuan yang bermartabat. Persoalannya, apakah tabarruj sebagaimana yang dikemukakan subjek, seperti itu pula yang dikehendaki konsep tabarruj dalam Qs. al-aḥzāb (33): 33 sehingga mengakibatkan haramnya bersanding pada pelaminan yang sama, semua ini akan dikemukakan pada sub tersendiri.

Subjek dari pemberi fatwa tampaknya memiliki pemahaman yang sama dengan para subjek sebelumnya tentang haramnya bersanding pada satu pclaminan bagi mempelai. Bahkan para pemberi fatwa ini juga menyatakan beberapa perilaku lain yang menyebabkan haramnya bersanding. Salah seorang pemberi fatwa mengatakan apabila resepsi tersebut diselenggarakan secara mewah, maka haram mengadakan acara persandingan. Menurutnya hal ini sebagai sebuah pemborosan yang sangat bertentangan dengan ajaran Islam QS. (17): 27 bahkan pelaku pemborosan, lanjutnya sebagai teman setan.

\section{Argumentasi hukum haramnya persandingan bagi mempelai}

\section{Ikbtilat}

Ikbtilät adalah bercampur baurnya laki-laki dan perempuan dalam suatu kegiatan. Seluruh subjek menyatakan haramnya bersanding bagi mempelai dalam resepsi perkawinan karena menyebabkan para tamu ber-Ikhtilat. Persoalannya, subjek tidak dapat memberikan jawaban yang pasti dasar-dasar hukum (al-Qur'an atau hadis) yang digunakan. Subjek hanya mengatakan perintah untuk memisahkan pelaminan dan tempat perjamuan tamu bersumber dari subjek pemberi fatwa, bahkan di antara subjek ada yang merasa khawatir akan didemonstrasi teman-teman kelompoknya apabila tidak melaksanakan fatwa yang diberikan.

Perilaku di atas sebenarnya bukan berasal dari kesadaran dan pengetahuan subjek terhadap hukum perkawinan Islam, sebaliknya ketundukan terhadap fatwz tersebut lebih memperjelas 
Bersanding dalam resepsi perkawinan: refleksi atas pandangan dan perilaku hukum...(Abdul Helim)

bahwa subjek sebenarnya hidup dalam tekanan doktrin dan terjebak dalam lingkaran taklid. Hal seperti ini sangat dilarang dalam Islam yang sejak lama mengajarkan kemerdekaan untuk bertindak sesuai dengan ilmu pengetahuan yang dimiliki untuk menentukan nasibnya sendiri. Dengan ketidakberdayaan subjek yang masuk dalam lingkaran taklid ini, membuat subjek kehilangan kendali untuk menentukan apakah memilih tunduk pada ajaran Tuhan atau tunduk pada suara kelompok. Subjek pun tampaknya tidak menyadari bahwa mercka melakukan praktik syirik (meletakkan otoritas pemberi fatwa di atas otoritas Tuhan) dan bid'ah sebagaimana mereka memvonis orang yang tidak sepaham dengan mereka sebagai pelaku bid'ah.

Berbeda halnya dengan subjek yang terdiri dari pemberi fatwa. Salah seorang di antaranya mengatakan kehidupan laki-laki dan perempuan pada dasarnya terpisah dan hal ini bukan berasal dari hasil dari pemikirannya, melainkan telah menjadi doktrin agama dan mengikutinya juga hanya semata-mata tunduk pada ajaran Agama Islam. Pemberi fatwa ini mengilustrasikan bahwa ketika melaksanakan salat laki-laki dan perempuan tidak bercampur baur, melainkan terpisah bahkan untuk menunjukkan keadaan terpisah yang sebenarnya digunakan pula bijäb. Oleh karena itu, lanjutnya, hal seperti inilah kehidupan antara laki-laki dan perempuan.

Pemberi fatwa di atas tampaknya terinspirasi pada hukum pemisahan antara laki-laki dan perempuan dalam melaksanakan salat, sehingga hukum bersanding pada resepsi perkawinan disamakan (diqiyarkan) dengan hukum pemisahan dalam melaksanakan salat. Atgumentasi hukum yang digunakan pemberi fatwa ini menurut hemat penulis setidaknya mengandung empat kelemahan. Pertama, para pemberi fatwa melupakan bahwa salat adalah salah satu yang masuk dalam rangkaian ibadat, sementara perkawinan termasuk dalam ruang lingkup muamalat, terlebih bersanding yang tidak disinggung nas baik al-Qur'an maupun hadis, dipastikan mendapatkan ruang yang lebih leluasa jika dibandingkan dengan salat. Kenyataannya, Islam membolehkan percampuran antara laki-laki dan perempuan dalam bidang muamalat seperti di pasar, di tempat kerja dan sebagainya.

Kedua, dalam pelaksanaan salat keteraturan merupakan kemestian baik keteraturan saf maupun keteraturan posisi laki-laki dan perempuan, sehingga apabila kemestian ini tidak dijaga dapat berakibat terganggunya pelaksanaan ibadat. Adapun pada resepsi perkawinan tempat duduk para tamu tidak mesti harus teratur dan tersusun seperti salat, sehingga apabila terjadinya campur baur para tamu, tidak menyebabkan status perkawinan mempelai laki- 
ljtihad, Jurnal Wacana Hukum Islam dan Kemanusiaan, Vol. 11, No. 2, Desember 2011: 165-181

laki dan perempuan yang telah menjadi suami isteri tersebut menjadi batal.

Ketiga, ikhtilāt para tamu dalam resepsi perkawinan atau bersandingnya kedua mempelai pada pelaminan yang sama merupakan sebuah urf (adat) yang lama berlaku di tengahtengah masyarakat dan dikenal masyarakat dengan baik, sehingga adat ini pun menjadi budaya masyarakat. Oleh karena itu, bersanding pada pelaminan yang sama pada saat resepsi perkawinan dan menyatunya tempat perjamuan tampaknya tidak mungkin dapat eksis sampai sekarang apabila dalam kegiatan tersebut memungkinkan para tamu berbuat buruk atau adanya perilaku asusila yang dilakukan para tamu.

Berbeda halnya dengan pesta untuk merayakan sebuah perkawinan yang dilangsungkan di klub atau di tempat-tempat hiburan malam dan sebagainya. Apabila hal ini dilakukan hampir dapat dipastikan adanya kecenderungan untuk berbuat hal-hal yang dilarang dalam agama, namun yang patut pula dipertimbangkan bahwa pesta tersebut sebenarnya tidak ada hubungannya dengan bersanding bagi mempelai pada resepsi perkawinan. Keempat, adanya indikasi kekacauan metodologis dalam istinbät hukum yang dilakukan para pemberi fatwa. Hal ini akan dibahas secara rinci pada sub tersendiri.

\section{Tabarruj}

Haramnya bersanding bagi mempelai menurut subjek disebabkan adanya kecenderungan bagi mempelai perempuan ber-tabarruj sebagaimana disebutkan dalam Q.S. al-aḥzāb (33): 33. Tabarruj adalah sebuah perilaku yang dilakukan orang-orang jahiliyah terdahulu. Dilihat dari segi oahasa, tabarruj berarti "tampak, tinggi, mewah" (Munawir, 1997: 70) atau "keterbukaan dan kejelasan bagi semua yang melihat" (al-Qurthubi, 2006: 340).

Maksud dari pengertian kebahasaan ini adalah untuk menunjukkan bahwa pada zaman jahiliyah dahulu adanya perempuan yang memakai pakaian yang dilapisi mutiara dan ia pun keluar rumah berjalan untuk memperlihatkan dirinya pada kaum laki-laki. Pakaian yang dipakainya pun sebenarnya pakaian yang hanya dapat dipakai di rumah (al-Zamakhsyari, 2006: 340). Pendapat lain mengatakan tabarruj adalah scorang perempuan yang mengenakan pakaian yang mestinya hanya pantas dipakai di rumah, karena di bagian samping pakaian tersebut terbelah dari bawah ke atas (tidak dijahit), lagi pula pakaian itu amat tipis sehingga badannya pun tidak tertutupi oleh kain (membentuk lekak-lekuk tubuh) (al-Qurthubi, 2006: 143). 
Bersanding dalam resepsi perkawinan: refleksi àtas pandangan dan perilaku hukum...(Abcul Helim)

Disebutkan dalam referensi lain, tabarruj adalah perilaku seorang percmpuan yang menampakkan keindahan tubuhnya yang sebenarnya wajib ditutupi (al-Maraghi, Juz XXII, 1946: 6-7). Pendapat lainnya, tabarrij adalah perempuan di zaman jahiliyah yang berjalan sambil herlenggak-lenggok dengan gaya menggoda (genit) (al-Dimasyq, juz 1 , 2000: 151). Pakar tafsir abad ini, Quraish Shihab mengatakan adanya larangan ber-tabarruj berarti larangan menampakkan "perhiasan" dalam pengertian yang umum yang biasanya tidak ditampakkan perempuan yang baik. Arti lainnya memakai sesuatu yang tidak wajar untuk dipakai, seperti berdandan berlebihan atau berjalan dengan berlenggak-lenggok (Shihab, vol. 2, 2000: 264). Benang merah yang dapat ditarik dari beberapa pendapat di atas bahwa tabarruj sebenarnya berperilaku, bergaya dan berpakaian secara seronok, serta terbuka, sehingga setiap mata yang melihat menikmati pemandangan sebagian dari anggota tubuh perempuan yang ada di hadapannya.

Menengok kembali pada situasi dan kondisi Arab pra Islam khususnya kebiasaan yang berlaku pada waktu itu bahwa para perempuan menyenangi pesta. Mereka juga memiliki kebiasaan untuk menari di tengah-tengah kerumunan laki-laki terpandang yang hadir ketika pesta diselenggarakan (Ali, 1978: 81). Begitu juga cara berpakaian perempuan merdeka atau budak yang baik dengan perempuan yang kurang atau tidak baik hampir tidak dapat dibedakan, sehingga seringkali terjadinya perbuatan kriminal pada perempuan yang berpakaian seperti yang dimaksudkan (Shihab, rol. 2, 2000: 319).

Apabila beberapa pandangan di atas ditemukan dengan argumentasi para subjek tentang haramnya bersanding pada satu pelaminan karena mempelai perempuan dalam keadaan berhias yang dikhawatirkan termasuk tabarruj sebagaimana disebutkan dalam al-aḥzāb (33): 33, maka penting ditegaskan bahwa cara berhias atau berpakaian mempelai wanita dalam setiap resepsi perkawinan sangat jauh berbeda dengan yang dimaksudkan konsep tabarruj di atas. Hal yang sebaliknya pakaian yang dikenakan mempelai perempuan khususnya di Indonesia dipandang layak dan terhormat, kecuali yang biasa tampak sebagaimana pada alNūr (24): 31. Beberapa anggota badan yang biasa tampak tersebut diukur sesuai dengan kebiasaan atau adat istiadat setempat dan adat istiadat suatu masyatakat tidak dapat dipaksakan terhadap masyarakat yang lain atas nama agama (Shihab, vol. 2, 2000: 332). 
ljtihad, Jurnal Wacana Hukum Islam dan Kemanusiaan, Vol. 11, No. 2, Desember 2011: 165-181

Adat berpakaian mempelai perempuan atau bahkan tata cara bersanding orang Arab sebenarnya tidak dapat dipaksakan kepada adat berpakaian mempelai perempuan Indonesia atau terkait juga dengan tata cara bersanding dalam resepsi perkawinan. Beberapa anggota badan yang biasa tampak menurut 'urf Indonesia adalah wajah, rambut, leher, tangan dan kaki dari lutut ke bawah. Hal ini sesuai pula dengan konsep kontekstual yakni melihat suatu persoalan mesti mengaitkan dengan situasi dan kondisi. Khususnya dalam persoalan ini tampaknya yang lebih relevan adalah membolehkan mempelai pengantin untuk bersanding pada satu pelaminan, karena masih termasuk ke dalam 'urf sab̆ĭ yakni adat istiadat yang dapat dibenarkan dan dipandang tidak bertentangan dengan nas atau pun logika umum.

\section{Mewab dan cenderung boros}

Salah satu alasan haramnya melakukan persandingan menurut subjek disebabkan resepsi perkawinan diselenggarakan secara mewah dan cenderung mengeluarkan biaya yang banyak (boros) sampai menghabiskan berpuluh-puluh juta bahkan miliaran rupiah. Pendapat subjek ini didasari dari al-Isrä' (17): 27 yang menyatakan bahwa orang yang cenderung atau berbuat boros adalah sahabat setan.

Argumentasi di atas sebenarnya kurang tepat, sebab mestinya yang menjadi sorotan

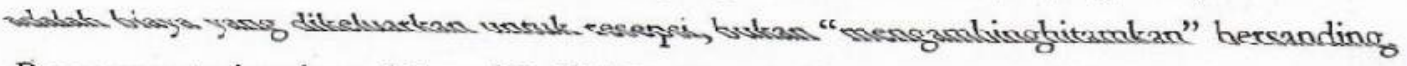
Pesan yang terkandung dalam al-Isrā' (17): 27 pada dasarnya menunjukkan pada pengertian setiap pr-buatan, termasuk pula dalam pembiayaan resepsi perkawinan. Oleh karena itu interpretasi para subjek perlu diarahkan agar tepat pada sasaran yang dituju bahwa resepsi perkawinan mesti diselenggarakan secara layak, sederhana dan tidak atau terkesan boros, sementara persandingan pada satu pelaminan tetap berjalan.

\section{Mengutamakan badiah, kado atau uang}

Satu argumentasi yang kurang tepat pula apabila mengaitkan haramnya kedua mempelai bersanding disebabkan adanya tujuan untuk mendapatkan hadiah, kado atau uang dari para tamu. Mestinya yang menjadi masalah adalah pelaksanaan acara resepsi tersebut. Maksudnya, tanpa melakukan persandingan pun sebenarnya resepsi perkawinan dapat diselenggarakan dan begitu pula sebaliknya tanpa mengadakan resepsi perkawinan dan cukup hanya 
Bersanding dalam resepsi perkawinan: refleksi atas pandangan dan perilaku hukum...(Abdul Helim)

diberitahukan (I'lan) kepada beberapa kerabat, persandingan dapat dilakukan. Oleh karena itu, keinginan untuk mendapatkan hadiah, kado atau uang sebenarnya tidak berkaitan dengan persandingan. Argumentasi subjek ini lebih tepat ditempatkan pada haramnya menyelenggarakan acara resepsi perkawinan karena hanya mengharapkan hadiah, kado atau

\section{Messuntut mabar yang tinggi}

Argumentasi yang masih kurang tepat adalah apabila mengaitkan haramnya kedua mempelai bersanding disebabkan menuntut mahar yang tinggi. Mestinya yang menjadi masalah adalah pelaksanaan acara resepsi tersebut. Oleh karena itu menurut hemat penulis penuntutan mahar yang tinggi memiliki hukum yang tersendiri dan permasalahan ini tidak berkaitan dengan persandingan. Argumentasi para subjek di atas lebih tepat ditempatkan pada tidak bolehnya para wali memberatkan calon mempelai laki-laki atau keluarganya untuk membina rumah tangga dengan anak mereka.

\section{Penaburan beras keuning}

Salah satu alasan yang dikemukakan subjek tentang haramnya bersanding bagi mempelai karena kedua mempelai ditaburi beras kuning yang tujuannya memberikan semangat kekuningan padi. Menurut subjek perilaku ini termasuk syirik karena melakukan sesuatu tidak atas nama Allah bahkan meminta untuk memberikan semangat selain kepada Allah.

Sebenarnya persoalan ini merupakan otoritas teologi. Kendati demikian apabila dilihat dari kacamata 'urf, hal ini telah menjadi kebiasaan masyarakat muslim, khususnya Melayu Banjar yang selalu menaburkan beras kuning kepada kedua mempelai baik disertai niat untuk memberikan semangat atau pun hanya sekedar melakukan kebiasaan. Menurut penulis persoalan tersebut tidak dapat dinilai dengan gegabah bahwa pelaku penabur beras kuning menjadi musyrik. Dipandang secara umum bahwa seorang muslimah yang menggunakan jilbäb (pakaian kurung seluruh tubuh, tanpa memperliharkan lekok tubuh) atau seorang muslim yang selalu menggunakan surban tidak dapat dijamin bahwa imannya lebih baik dari muslimah atau muslim yang tidak sama dengannya. Terlebih dalam persoalan akidah yang sebenarnya terletak pada batin setiap orang, sehingga kualitas akidahnya hanya diketahui oleh dirinya dan Allah serta tidak dapat dinilai melalui simbol-simbol formal. 
Ijtihad, Jurnal Wacana Hukum Islam dan Kemanusiaan, Vol. 11, No. 2, Desember 2011: 165-181

Apabila ingin pula melihat simbol-simbol yang dilakukan ketika menabur beras kuning pada mempelai, adat atau kebiasaan yang berlaku secara umum baik masyarakat Melayu Banjar, masyarakat Dayak Bakumpai atau pun Ngaju Kalimantan Tengah yang muslim sclalu menycrtakan shalawat kcpada Nabi Muhammad saw. ketika menabur beras kuning tersebut. Artinya walau pun menabur beras kuning ini datang dari budaya non Islam, namun dengan adanya bacaan shalawat tersebut tampaknya dapat menjadi budaya yang patut dipertimbangkan sebagai budaya islami. Hal ini tidak ada bedanya dengan seseorang yang membeli kain khas buatan Barat beserta desainnya (baca: non muslim) yang secara teologis normatif memiliki pertentangan akidah dengan muslim, namun sesampai di dunia Islam kain tersebut dimodifikasi untuk dibuat pakaian yang sesuai dengan ajaran Islam yang akhirnya ia disebut sebagai busana Muslim atau Muslimah.

\section{Metode istinbāt hukum ikbtilāt}

Metode istinbät yang digunakan pemberi fatwa khususnya berkaitan dengan hukum ikebtilät tampaknya menggunakan metode qiyas. Hal ini terlihat dari penjelasan pemberi fatwa yang mengharuskan laki-laki dan perempuan terpisah atau menggunakan bijäb pada sctiap persoalan sebagaimana ketentuan dalam pelaksanaan dalam salat. Qiyäs dalam ilmu usul fikih diartikan sebagai upaya yang dilakukan untuk menyamakan status hukum yang tidak diatur dalam nas (al-Qur'an atau hadis) kepada status hukum suatu persoalan yang telah diatur $\mathrm{d}^{-1}$ am nas disebabkan adanya persamaan 'illab (Mallah, juz I, 2001: 444-445).

Sctiap orang yang ingin menggunakan metode qijyäs mesti memperhatikan rukun dan syarat qijass. Rukun yang mesti terpenuhi adalah așl, furü', 'illah dan hukum as.l. As:l adalah suatu peristiwa yang telah ada diatur dalam nas, furu' adalah peristiwa baru yang tidak diatur dalam nas, 'illah adalah motivasi timbul dan terjadinya hukum dan hukum aș/ adalah status hukum suatu peristiwa yang ditetapkan dalam nas (Hasballah, 1997: 106). Dikaitkan dengan kajian ini, aș adalah terpisahnya tempat melakukan salat bagi laki-laki dan perempuan, furúadalah terpisahnya tempat persandingan mempelai laki-laki dan perempuan dan hukum ast-nya adalah wajib. Kewajiban ini karena adanya persamaan 'illab yaitu menghindari terjadinya fitnah antara laki-laki-laki dan perempuan atau supaya teraturnya pelaksanaan baik pada salat maupun pada persandingan. 
Bersanding dalam resepsi perkawinan: refleksi atas pandangan dan perilaku hukum...(Abdul Helim)

Persoalan yang ditemukan, pemberi fatwa tampaknya menyamakan antara 'illab dan tik mah hukum, sementara diketahui bahwa kedua hal tersebut berbeda walau saling berkaitan. Wub adalah suatu sifat yang berada pada așl (Zuhaily, juz II, 2001: 606) atau sebagai sesuatu yang mempengaruhi adanya hukum, (al-Ghazali, 2000: 310), dan dapat pula diartikan sebagai sesuatu yang memotivasi adanya hukum, (al-Amidi, jilid II juz III, 1996: 137), bahkan sebagai bal yang melatarbelakangi adanya hukum. 'Illab ini juga merupakan sifat zahir dari suatu hakum yang dapat diukur, sementara hikmah hukum merupakan persoalan yang masih samar, sulit diukur dan ditangkap panca indera bahkan masing-masing individu dapat berbeda dalam memandang suatu hikmah. (Yahya \& Fathurrahman, 1993: 84) dan (Haroen, 1995: 80). Hal in sesuai dengan makna hikmah hukum itu scndiri al-ghayah al-bå̃dah al-maqsüdah rakni sesuatu yang sampai mencapai titik tujuan yang paling jauh sebagaimana dimaksudkan dan tujuan tersebut adalah untuk mencapai kemaslahatan dan menghindari kemudaratan Zuhaily, juz II, 2001: 651). Dikatakan dalam bahasa sederhana hikmah adalah tujuan yang ingin dicapai dengan pensyari'atan hukum.

Menghindari terjadinya fitnah antara laki-laki-laki dan perempuan atau supaya teraturnya pelaksanaan baik pada salat maupun pada persandingan, menurut hemat penulis sebenarnya bukan termasuk 'illah hukum, melainkan lebih tepat termasuk hikmah hukum, karena penghindaran terjadinya fitnah merupakan tujuan hukum, bukan sebagai motivasi adanya hukum. Oleh karena itu, penyamaan hukum yang dilakukan pemberi fatwa, tidak memenuhi ketentuan-ketentuan rukun dan syarat metode qiyas yakni tidak terpenuhinya ketentuan illab hukum, bahkan qiyas hukum yang dinyatakan pemberi fatwa bertentangan dengan nas. Salah satunya adalah bahwa fakta sejarah menyatakan praktik yang dilakukan pada zaman Nabi, laki-laki dan perempuan bercampur baur dalam menyelesaikan urusan muamalat. Perkawinan merupakan ruang lingkup muamalat (urusan keduniaan), scbagaimana Tuhan sclalu menyandingkan kata al-dunyā dan al-äkbirah yang sebenarnya juga menunjukkan adanya urusan dunia dan ada pula urusan akhirat.

Model qiyās yang digunakan pemberi fatwa tampaknya dapat dikategorikan sebagai qiyās fasid yakni qiyās yang rusak, sehingga fatwa wajibnya memisahkan tempat persandingan dan perjamuan tamu yang di-qija $\bar{s}$-kan terpisahnya saf shalat antara laki-laki dan perempuan tidak dapat diterima. Hal sebaliknya, agar dapat menjadi qiyas saḅịh (qiyās yang benar) adalah 
Ijtihad, Jumal Wacana Hukum Islam dan Kemanusiaan, Vol. 11, No. 2, Desember 2011: 165-181

menyatunya tempat persandingan mempelai dan bercampur baurnya tamu laki-laki dan perempuan disamakan hukumnya dengan bolchnya laki-laki dan perempuan bercampur baur dalam urusan keduniaan seperti yang terjadi pada zaman Nabi. Praktik yang terjadi di zaman Nabi disebut sebagai aș, masalah persandingan disebut furz, dan karena pada dasarnya laki-laki dan perempuan saling berpasangan; tidak dapat dipisahkan disebut 'illah, serta bolehnya bercampur baur tersebut disebut hukum așl.

\section{Metode istinbāt hukum tabarruj}

Pemberi fatwa tampaknya terjebak dalam pemahaman mereka yang memandang cukup menggunakan metode žăbir, (Shalih, jilid I, 1993: 143) atau dilälab 'ibärah atau bahkan mantūuq, (Khin, 1994: 128 dan 138) (literal-tekstual-normatif) untuk memahami ayat-ayat Al-Qur'an atau hadis Nabi. Gaya berpikir pemberi fatwa ini tampaknya tepat pula disebut sebagaimana yang diistilahkan Yusuf Qaradhawi sebagai kelompok Neo-al-Z̄äbiñ (penerus baru mazhab Zäbiñ) (Qaradhawi, 2007: 37 dan 41). Akibatnya, produk hukum yang diproduksi kurang relevan dengan keadaan yang terjadi saat ini, khususnya berkaitan dengan penampilan mempelai perempuan. Gaun yang digunakan mempelai perempuan saat ini tampaknya tidak ada yang memperlihatkan anggota tubuh dari lutut sampai ke bawah pusat atau dada mempelai perempuan, sehingga dengan gambaran ini sebenarnya menunjukkan gaun yang digunakan adalah gaun yang layak dan terhormat serta bermartabat. Konsep tabarrij tersebut tampaknva lebih tepat apabila diarahkan untuk menilai tata cara berpakaian masyarakat secara let.in luas seperti yang terjadi saat ini, bahkan di antaranya ada hampir dikatakan tidak menggunakan pakaian.

Pemberi fatwa cenderung berbuat gegabah dan selalu menggunakan pendekatan teologis normatif tanpa memahami maksud nas, situasi dan kondisi saat lahirnya nas serta mengaitkan pula dengan situasi dan kondisi di masa sekarang. Akibatnya fatwa yang diproduksi mengalami kekeringan, kurang subur tumbuh dalam pemahaman masyarakat dan cenderung mempersulit.

Terbukti melalui hasil penelitian ini, pemberi fatwa meletakkan nas sepertinya bukan pada yang seharusnya. Mengharamkan persandingan karena acara resepsi perkawinan diadakan secara mewah, sehingga dinilai sebagai pemborosan. Mereka juga mengharamkan bersanding, karena adanya tuntutan mahar yang terlampau tinggi dan karena pihak wali 
lebih mengutamakan hadiah, kado atau uang. Apabila dipahami, baik melalui kaidah zăhir, atau dilälab 'ibārab atau bahkan mantūq, terlebih melalui logika, semua dalil-dalil argumentasi fang disebutkan tidak berkaitan dengan bersanding dan apabila dikaitkan sebenarnya lebih rerfokus pada penyelenggaraan acara resepsi tersebut. Oleh karena itu, bukan bersanding rang diharamkan, melainkan penyelenggaraan resepsi tersebut yang perlu disederhanakan.

\section{Penutup}

Perilaku hukum yang dianggap haram dalam acara bersanding saat resepsi perkawinan menurut subjek adalah bercampur baurnya para tamu baik laki-laki maupun perempuan (ikbtilat $t$ ) di acara tersebut, sehingga dikhawatirkan dapat menimbulkan fitnah. Perilaku lainnya, adanya nuansa tabarruj karena mempelai perempuan berhias untuk dipertontonkan. Hal lainnya adalah menuntut mahar yang tinggi kepada mempelai laki-laki, mengutamakan hadiah, kado, atau uang dari para tamu, termasuk pula menaburkan beras kuning untuk memberikan semangat kepada mempelai. Perbuatan seperti ini menurut para subjek termasuk dalam kategori syirik.

Subjek tidak mengetahui secara pasti argumentasi hukum haramnỵa persandingan bagi mempelai dan mereka hanya mengikuti pendapat pemberi fatwa. Pemberi fatwa pun tidak memiliki argumentasi yang reliable baik dari al-Qur'an maupun dari hadis dan hanya menyatakan tidak terdapat dalam ajaran Nabi Muhammad menyandingkan mempelai lakilaki dan perempuan pada satu pelaminan, terlebih dalam ajaran Islam kehidupan laki-laki dan perempuan sebenarnya terpisah. Oleh karena itu dalam resepsi perkawinan baik mempelai laki-laki dan perempuan atau pun para tamu harus dipisah, sebagaimana terpisahnya lakilaki dan perempuan ketika melaksanakan salat. Pemberi fatwa justru membolehkan bercampur baurnya laki-laki dan perempuan dalam beberapa kegiatan seperti di pasar atau di tempat kerja, sebab hal ini telah dipraktikkan di zaman Rasulullah. Argumentasi para subjek ini tampak sulit diterima logika manusia dan usul fikih, sebab potensi kemudaratan bercampur baurnya laki-laki dan perempuan baik di pasar atau di tempat kerja lebih besar jika dibandingkan dengan potensi kemudaratan bercampur baumya laki-laki dan perempuan di acara resepsi perkawinan. Oleh karena itu pula, argumentasi subjek ini dipandang mengandung kelemahankelemahan yang cenderung menjebak kehidupan keberagamaan umat Islam sendiri. 
Ijtihad, Jurnal Wacana Hukum Islam dan Kemanusiaan, Vol. 11, No. 2, Desember 2011: 165-181

Pemberi fatwa pun tidak memiliki metode istinbät dari usul fikih, bahkan istilah istinbät dan usul fikih sebagai metodologi fikih kurang familiar di kalangan mereka. Oleh karena itu, tidak mengherankan apabila produk hukum yang diproduksi tampak kering dan mengalami kekacauan metodologis. Mereka memisahkan tempat persandingan dan tempat perjamuan antara laki-laki dan perempuan karena mengqijāskan pada keharusan memisahkan tempat salat bagi laki-laki dan perempuan, padahal tidak memenuhi rukun dan syarat qijyas, sehingga disebut qiyas fasid. Mereka juga menyatakan bahwa persandingan tersebut termasuk tabarruj, sementara yang dimaksud dengan tabarrij adalah berperilaku genit, berjalan meliuk-liuk dan berpenampilan seronok juga terbuka (tebar pesona). Mereka juga mengharamkan mempelai laki-laki dan perempuan bersanding, karena ketika prosesi lamaran pihak perempuan menuntut mahar yang terlampau tinggi atau mengutamakan hadiah dan uang ketika resepsi perkawinan, termasuk pula menaburkan beras kuning, sementara beberapa hal tersebut sama sekali tidak berhubungan dengan persandingan. Lebih tepatnya beberapa persoalan itu diarahkan untuk menyatakan terlarangnya mengadakan resepsi perkawinan.

Daftar pustaka

Al-Dimasyq, Abi al-Fida Ismail Ibn Katsir. Tafsir al-Qur'an al-'Ažnim. juz II. Yaman: Maktabah

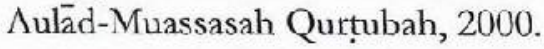

Al-Amidi, Saifuddin Abi al-Hasan 'Ali ibn Abi 'Ali ibn Muhammad. al-Iḅkeām fî̀ Ușül alAḅkām. jilid II juz III. Bcirut-Libanon: Dār al-Fikr, 1996.

Al-Bukhary, Abi Abdullah Muhammad bin Ismail. Al-Jämi' al-Saḅị. juz III. Kairo: Maktabah Sala yah, t.th.

Al-Ghazali, Abi Hamid Muhamamd bin Muhammad bin Muhammad. al-Mustashfa $f \hat{i} \mathrm{Ilm}$ al-Ușül. Beirut-Libanon: Dār al-Kutub al-Ilmiyah, 2000.

Ali, Syed Ameer. Api Islam. diterjemahkan oleh H.B. Jassin. Jakarta: Bulan Bintang, 1978.

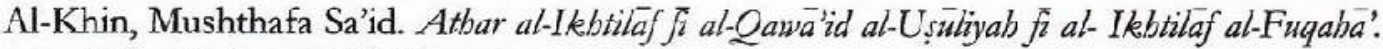
Beirut-Lebanon: Mu'assasah al-Risālah, 1994.

Al-Maraghi, Ahmad Musthafa. Tafsīi al-Maräghì. juz XXII, T.tp: Musțafã al-Bāb al-Ḥalibi, 1946.

Al-Qurthubi, Abi Abdillah Muhammad IbnAhmad Ibn Abi Bakr. Al-jāmi' al-Aḥkām alQur'ān. juz XV. Beirut: Muassasah al-Risālah, 2006.

Arikunto, Suharsimi. Manajemen Penelitian. Jakarta: Rineka Cipta, 1990. 
Bersanding dalam resepsi perkawinan: refleksi atas pandangan dan perilaku hukum...(Abdul Helim)

Al-Qustany,"Adat Bersanding: Pandangan Islam", Oktober 2009, http:// fazakkeer. blogspot.com/2009/10/adat-bersanding-pandangan-islam.html, (online 2 Pebruari 2010).

Al-Zamakhsyari, Abi al-Qasim Ibn Umar. Tafsir al-Kashshäf. juz V. Riyadh: Maktabah alAbikan, 1998.

Basyir, Muhammad, "Tradisi Perkawinan bagi Anggota Hizbut Tahrir (Studi Kasus terhadap 5 Anggota Jama'ah Hizbut Tahrir di Kota Palangka Raya)", Skripsi STAIN Palangka Raya, 2008.

L-Indragiry,"Baarakallaabu Laka...", Juli 2008, http://askar-islam.blog.friendster.com/ 2008/07/baarakallaahu-laka/, (online 2 Pebruari 2010).

Hanif, "Tunang Tak Mahu Bersanding", Desember 2007, http://clubni.multiply.com/journal/item/33/Tunang_Tidak_Mahu_Bersanding, (online 19 Pebruari 2010).

Haroen, Nasrun. Usul Fikib I. Jakarta: Logos, 1995.

Hasballah, 'Ali. Ușül al-Tashrī' al-Islami. Kairo: Dār al-Fikr al-'Arabi , 1997.

Jawas, Yazid bin Abdul Qadir, “Konsep Islam tentang Perkawinan”, Januari 2010, http:// ismailmusa.net/konsep-islam-tentang-perkawinan. $h t m l$, (online 2 Pebruari 2010).

Mahdiyah, Nur Mawaddah, "Hukum Bersanding Mengikut Perspektif Islam", Januari 2010, http://nurmawaddahmahdiyah.blogspot.com/2010/01/hukum-bersandingmengikut-perspektif.html, (online 2 Pebruari 2010).

Mallah, Husain Muhammad. al-Fatāwā: Nash'atuhā wa Tatannuruhāa Ușülubā wa Tațbiqatubā. juz I, cet. I. Beirut: al-Maktabah al-'Ashriyah, 2001.

Munawir, Ahmad Warson. Al-Munawnir Kamus Arab-Indonesia. Surabaya: Pustaka Progressif, 1997.

Rahman, Fazlur. Metode dan Alternatif Neomodernisme Islam. diterjemahkan dan disunting oleh Taufik Adnan Amal. Bandung: Mizan, 1989.

Rahman, Fazlur. Islam. diterjemahkan oleh Seoraji Saleh. Jakarta: Bumi Askara, 1992.

Sabiq, Sayyid. Fiqh al-Sunnah. jilid II. Kairo: Dār al-Fath, 1995.

Shalih, Muhammad Adib. Tafsir al-Nușüșfi al-Figh al-Islami. jilid I. Beirut-Libanon: al-Maktab al-Islāmi, 1993.

Shihab, Quraish. Tafsir al-Misbbab: Pesan, Kesan dan Keserasian Al-Qur'an. Jakarta: Lentera Hati, 2000.

Yahya, Muhktar dan Fathurrahman. Dasar-Dasar Pembinaan Hukum Fiqb Islam. Bandung: alMa'arif, 1993.

Zuhaili, Wahbah. Ușül al-Fiqh al-Islāmì. juz II. Damaskus-Suriah: Dār al-Fikr, 2001. 